\title{
sciendo

\section{Single Cell Oil Production from Waste Biomass: Review of Applicable Industrial By-Products}

\author{
Kriss SPALVINS $^{1 *}$, Ilze VAMZA ${ }^{2}$, Dagnija BLUMBERGA ${ }^{3}$ \\ ${ }^{1-3}$ Institute of Energy Systems and Environment, Riga Technical University, \\ Azenes iela 12/1, Riga, LV-1048, Latvia
}

\begin{abstract}
Single cell oil (SCO) is an attractive alternative source of oil, which, depending on the fatty acid composition, can be used as a feedstock for biodiesel production, as an ingredient for pharmaceuticals or as a source of essential fatty acids for human and animal consumption. However, the use of SCO is limited due to use of relatively expensive food or feed products in the cultivation of SCO producing microorganisms. In order to reduce SCO production costs, the use of cheaper feedstock such as biodegradable agro-industrial wastes are necessary. At the same time, the microbial treatment of biodegradable wastes ensures the neutralization of environmentally harmful compounds and reduces the negative impact on the environment. Oleaginous microorganisms are capable of fermenting a variety of industrial by-products, waste products and wastewaters, however further discussion on properties of the waste materials is necessary to facilitate the selection of the most appropriate waste materials for SCO production. Thus, this review compares various industrial waste products that can be used as cheap feedstock for the cultivation of SCO producing microorganisms. Industrial waste products, by-products and wastewaters are compared according to their global availability, current use in competing industries, required pre-fermentation treatments, oleaginous microorganism cell concentrations and SCO yields.
\end{abstract}

Keywords - Animal feed; biodiesel; industrial waste; low-cost substrate; microbial oil; oleaginous microorganisms; resource availability

\section{INTRODUCTION}

Waste recycling can significantly reduce the negative impact on the environment and, at the same time, reduce the costs associated with waste management. However, most of the waste is still being recycled using low-added value solutions [1] such as incineration [2], biogas production [3], or bioenergy and biofuel production [4]. In order to increase revenue generated by waste management, it is necessary to introduce new technological solutions, which would enable the use of biodegradable waste products in production of high added value products such as building block chemicals [5], [6] single cell proteins [1], [7], enzymes [8] and others. One of these high added value products is single cell oil (SCO).

\footnotetext{
* Corresponding author.

E-mail address: kriss.spalvins@rtu.lv
} 
Single cell oils are lipids derived from bacteria, fungi, yeasts, microscopic algae and protists. Depending on their fatty acid composition, these lipids have different applications. SCOs with high saturated fatty acid contents are suitable for the biodiesel production [9], while SCOs rich in polyunsaturated fatty acids are suitable for human and animal nutrition as well as for production of pharmaceuticals [10], [11]. These oils are similar in composition to those that can be obtained from plants and animals, but SCO has several advantages over traditional oil sources:

- A wide range of microorganisms can be used for SCO production. So far, hundreds of microorganisms from more than 60 genera have been identified as suitable for SCO production, capable of accumulating at least $20 \%$ oil relative to its biomass dry weight [11]-[13];

- The growth of microorganisms is considerably faster than growth of plants or animals. Microscopic algal populations double within 2-6 hours, yeast and microscopic fungi populations in 1-3 hours and bacterial populations double within $0.5-2$ hours. Therefore, microbial reactors require an oil synthesis cycle of $12-72 \mathrm{~h}$ for bacteria and 5-10 days for yeast, fungi and algae, while it is possible to harvest agricultural produce only once a season (1-2 times a year);

- Thanks to the rapid growth of microorganisms, suitable strains of microorganisms can be chosen and artificially selected in a few weeks or months, while breeding takes years with plants and animals;

- Microorganisms have several times higher oil content in dry matter than plants and animals (20-80\% for microorganisms, 5-35\% for plants, 2-30\% for fish) [11], [14];

- The composition of SCOs is of higher quality than that of oils derived from plants or fish. For example, the concentration of high-quality omega-3 fatty acids (EPA and DHA) from the total oil content of SCOs can reach up to $40 \%$, while for plants and fish it is $4.9 \%$ and $3 \%$, respectively [11];

- Microorganisms can use different sources of carbon for nutrients. Consequently, it is possible to extract oil using different types of biodegradable waste products with high carbon or carbohydrate content, thus significantly reducing production costs;

- Autotrophic microorganisms (microscopic algae, photosynthetic bacteria) are capable of growing using $\mathrm{CO}_{2}$ as a carbon source. Thanks to the Wood-Ljungdahl biochemical cycle or reverse Krebs cycle, microorganisms are 3 to 10 times more efficient $\mathrm{CO}_{2-}$ absorbers than plants [15], which generally ensures faster biomass growth and reduced negative environmental impacts;

- The cultivation of microorganisms for oil extraction is independent of seasonal weather conditions and climatic changes. The process of cultivation in the reactors is protected from extreme weather conditions, which usually destroy plant crops grown for oil production. Unlike plants, microorganisms that do not require light for growth, can be cultivated around the clock;

- Cultivation of microorganisms consumes considerably less water than cultivation of crops in agricultural areas. Due to the evaporation, transpiration and leakage of water, average water consumption per $1 \mathrm{~kg}$ of cereal is an average of 1800 litres [16]. When cultivating microorganisms in bioreactors, none of these factors have any effect on water consumption;

- The cultivation of microorganisms does not require fertile land, so it does not compete with agriculture. Due to low water consumption, SCO production can also be done in dry climate regions where the availability of fertile land is limited. 
All of these advantages have served as a basis for increased use of SCO and SCOs are now used in infant formulas, nutritional supplements and production of pharmaceuticals [10], [11]. However, the SCOs used in these industries are produced from microbial fermentations of raw materials such as refined sugars. By using so-called food and feed materials, the total cost of production is considerably increased [11], [13]. This increase in cost makes SCO production unprofitable for sectors with relatively lower added value, such as biofuels and animal feeds. Therefore, in order to be able to use SCO in these sectors, it is necessary to use cheaper raw materials such as biodegradable by-products, waste products and wastewaters from other industries [13], [17].

Industrial waste is any industrial residue that is not further used in the relevant systems. Industrial waste can come from factories, industries, mills and mining operations [13]. Although industrial waste includes residues such as chemical solvents, pigments, dyes, metal processing waste, radioactive waste, etc., only biodegradable industrial wastes such as sludge, paper waste and production residues, specific industrial and chemical by-products and waste gases can be used for microbial fermentation [7]. Spalvins and Blumberga [13] reviewed the most suitable agricultural by-products for SCO production. Within the framework of this review, the reviewed industrial wastes will be residues suitable for the production of SCO, that are not directly related to agriculture or food production. Other reviews which summarize the use of suitable waste products for production of SCO [11], [18]-[22], the main focus is on the used microorganisms and not so much on the properties of the waste products. Thus, in this review, waste products will be categorized, compared and described according to their availability, required pre-fermentation treatments, SCO yields, oleaginous microorganism biomass concentrations and current use in other industries, to facilitate the selection of the most suitable waste products. It is necessary to emphasize that, in order to do a complete availability analysis, each potential waste product needs to analysed by taking into account its costs, local availability, transportation requirements and necessary logistics and infrastructure systems. Carrying out such an analysis for each of the waste products described in the review is beyond the scope of this review, but the subject of the full availability analysis for waste products is further discussed by Spalvins and Blumberga [17].

\section{WASTE TYPES}

Spalvins et al. [7] categorized the most suitable industrial wastes for single cell protein (SCP) production in 3 groups: polymer-rich sources; carbon compounds; sources for photosynthetic microorganisms. These groups will also be used to categorize waste products in this review. Although the waste products described in the previous paper were reviewed in regard to SCP production [7], they are also suitable for SCO-producing microorganisms and vice versa, since waste products serve mostly as a carbon source in the fermentation medium. For example, yeast Yarrowia lipolytica can be cultivated using leaf juice as a substrate, but a paper reporting it [23] focused on using this yeast for production of SCP, not SCO. In this example it does not matter if leaf juice is used as a carbon source, since the difference between turning Yarrowia lipolytica into SCP or SCO producing unit is the difference between $\mathrm{C} / \mathrm{N}$ ratios, while the source of carbon is irrelevant. For this reason, previously reviewed waste products such as paper waste, acetic acid and hydrocarbons were not repeatedly described in this review, although they were listed in the summary table (Table 1) to compare SCO yields. New or additional information in regard to SCO production was provided for previously described waste products such as glycerol and sewage sludge. 


\section{COMPARISON OF INDUSTRIAL BY-PRODUCTS}

TABLE 1. INDUSTRIAL WASTES APPLICABLE FOR SCO PRODUCTION

\begin{tabular}{|c|c|c|c|c|}
\hline Polymer-rich sources & Microorganisms & DCW, g/l & LC, \% & Ref. \\
\hline Paper mill sludge & Cryptococcus vishniaccii & 14.6 & 53.40 & [24] \\
\hline \multirow[t]{2}{*}{ Waste paper hydrolysate } & Cryptococcus curvatus & 17.6 & 52.2 & [25] \\
\hline & Cryptococcus curvatus & 15.20 & 37.8 & [26] \\
\hline Sewage sludge & Lipomyces starkeyi & 9.5 & 68 & [27] \\
\hline \multicolumn{5}{|l|}{ Carbon compounds } \\
\hline Glycerol & Cryptococcus curvatus & 118 & 25 & [31] \\
\hline$"$ & Schizochytrium sp. & 151.40 & 52.36 & [32] \\
\hline Glucose and glycerol & Schizochytrium limacinum & 88.32 & 83.84 & [28] \\
\hline$"$ & Schizochytrium limacinum & 34.43 & 27.62 & [29] \\
\hline$"$ & Yarrowia lipolytica & 17 & 38 & [35] \\
\hline$"$ & Schizochytrium limacinum & 26.4 & 75 & [29] \\
\hline Crude glycerol & Schizochytrium limacinum & 11.78 & 26 & [30] \\
\hline$"$ & Rhodosporidium babjevae & 9.9 & 34.9 & [33] \\
\hline$"$ & Rhodosporidium diobovatum & 14.1 & 63.7 & [33] \\
\hline$"$ & Kodamaea ohmeri & 10.50 & 32.2 & [34] \\
\hline$"$ & Trichosporonoides spathulata & 10.40 & 44.5 & [34] \\
\hline$"$ & Yarrowia lipolytica & 8.1 & 43 & [36] \\
\hline$"$ & Yarrowia lipolytica & 4.92 & 30.1 & [37] \\
\hline$"$ & Yarrowia lipolytica & 8.1 & 43 & {$[38]$} \\
\hline Sodium gluconate & Rhodococcus opacus & - & 80 & [39] \\
\hline$"$ & Gordonia sp. & - & 72 & [39] \\
\hline Butanol wastewater & Trichosporon dermatis & 7.4 & 13.5 & [40] \\
\hline Acetic acid & Cryptococcus curvatus & - & 60 & [41] \\
\hline Tetradecane & Rhodococcus opacus & 1.89 & 62 & [39] \\
\hline$"$ & Gordonia sp. & 2.01 & 60 & [39] \\
\hline Hexadecane & Gordonia sp. & 1.89 & 58 & [39] \\
\hline Dodecane & Rhodococcus opacus & 0.70 & 84 & [39] \\
\hline \multicolumn{5}{|c|}{ Sources for photosynthetic microorganisms } \\
\hline Carbon dioxide & Dunaliella tertiolecta & - & 44 & [42] \\
\hline$"$ & Chlorella vulgaris & 2 & 38 & [43] \\
\hline
\end{tabular}

Note: DCW - dry cell weight (grams per litre of medium); LC - lipid content (\% of DCW).

\subsection{Polymer-Rich Sources}

Cellulose, hemicellulose and sludge fibres as waste are accumulated from paper industry, municipal waste and wastewater treatment systems. Polymers, such as lignocellulosic wastes are the most widely available industrial wastes. These polysaccharides require mechanical, 
chemical or biochemical pre-treatments to break down polymers and make fermentable carbohydrates available to oleaginous microorganisms, which in turn increases the cost of SCO production [7].

\subsubsection{Paper Mill Sludge}

Paper mill sludge (PMS) is a waste product generated during paper production. Approximately 30-50 kg of PMS is generated per tonne of paper produced [24], [44]. Thus, every year, the global paper industry generates around 17 million tonnes of PMS [7], [45], from which most of it is dumped in landfills, used in land applications or incinerated [46], [47]. Since PMS is available in large amounts and has not been efficiently utilized thus far, its use in SCO production would be an appropriate value-added solution. PMS is rich in organic compounds and micro and macro nutrients [46], [47]. The composition of PMS varies greatly depending on the type of wood used for paper production, the amount and type of used recycled paper, applied production technology, the target product and other factors [46], [47]. In general, the main components in PMS are cellulose, hemicellulose and lignin, but compared to other lignocellulosic waste products, lignin content in PMS is significantly reduced due to the pulping process [24]. Reduced lignin concentrations significantly improve PMS fermentability and alleviate necessity for extensive pre-treatment processes, which are required for other lignocellulosic materials, thus significantly affecting overall cost of production [1], [7], [24]. Due to these properties, pre-treatment methods such as ultrasonication can be used for preparing PMS for microbial fermentation. Ultrasonication ensures break down of cellulose and hemicellulose and release of fermentable carbohydrates [24], [27]. The high cellulose content ensures that hydrolysed PMS is rich in glucose, xylose, arabinose and other fermentable sugars.

Spalvins et al. [7] previously described the availability and use of waste paper for cultivation of SCP-producing microorganisms. Similar to paper waste, PMS is contaminated with unwanted microorganisms and since the aforementioned ultrasonication pre-treatment does not sterilize the material, a further sterilization is required to control microbial contamination. An interesting solution to this problem would be the use SCO-producing extremophiles [48], [49], thus enabling application of selective growth conditions in the PMS medium. Thus far, good SCO yields have been reported by using PMS as substrate in Cryptococcus vishniaccii culture. Cryptococcus vishniaccii is psychrophilic yeast which is capable of growth at temperature ranges from $4{ }^{\circ} \mathrm{C}$ to $26{ }^{\circ} \mathrm{C}$ [50], although in previously mentioned report selective temperatures were not used during fermentation. The use of PMS in SCO production has not been extensively studied, but the reported SCO yields indicate that this substrate is promising [24] and additional research on PMS as well as on paper waste in SCO production are required [7], [25], [26].

\subsubsection{Sewage Sludge}

Sewage sludge is a waste product generated by wastewater treatment plants. In European Union alone about 33 million tonnes of sewage sludge are generated annually [51]-[54]. The use of sewage sludge in land applications is limited due to risk of contaminating soil and water with heavy metals and toxic organic compounds. For these reasons, sewage sludge is mainly disposed in landfills or dried and then burned [27]. Value added and environmentally friendly alternatives to sewage sludge management include: use in biogas production, as well as aerobic fermentation for SCO production, where the produced oil could be used for biofuel production [27]. Another interesting alternative is the use of oleaginous microorganisms directly in aerobic 
wastewater treatment systems [55]. In this way, the sludge's lipid content would be significantly increased and it would enable the use of the sewage sludge as a direct feedstock for the production of biodiesel, without the need to separately treat sewage sludge afterwards.

Usually, sewage sludge is rich in proteins, carbohydrates, fats, fibres, nitrogen compounds and also contains phosphorus and sulphur compounds and many other micro and macro elements [56], [57]. Sewage sludge have high organic carbon concentrations, which are mainly found in the form of fibres, thus hydrolysis of the sludge can ensure the breakdown of fibres and release of fermentable carbohydrates [27]. Sewage sludge has high nitrogen concentrations and the average $\mathrm{C} / \mathrm{N}$ ratios are around 6 [56], [57], which means that in order to efficiently use sewage sludge in SCO production, it is necessary to significantly increase carbon concentrations by additionally adding other carbohydrate-rich by-products. Thus far, good SCO yields have been reported by [27] when Lipomyces starkeyi was cultivated in treated sewage sludge enriched with glucose to reach appropriate $\mathrm{C} / \mathrm{N}$ values [27]. Due to the high concentrations of nitrogen, proteins, fatty acids and micro and macronutrients, sewage sludge can serve as cheap and efficient feedstock which, when combined with additional carbon source, can deliver high SCO yields while maintaining low production costs.

\subsection{Carbon Compounds}

Butyric acid, acetic acid, glycerol and other organic compounds are generated in various industries as products, by-products or residues. These compounds can be directly used as carbon and amino acid sources for SCO production, while at the same time enabling the treating of industrial effluents.

\subsubsection{Glycerol}

In the last 15 years the production volumes of biodiesel have increased significantly, due to the compatibility of biodiesel and its production technology with the already existing fuel industry infrastructure, the relatively simple production process, the possibility of using various raw materials in the production process and subsidies to producers [58]. Global biodiesel production in 2014 reached 26.5 million tonnes a year, which is more than a 4 -fold increase, when compared with the production volumes in 2006 [58], [59]. Even though this increase is a good example of greenhouse gas emission level reduction and an example of renewable energy sector development [60], biodiesel production creates $100 \mathrm{~kg}$ of crude glycerol per each tone of biodiesel [2]. It means that each year more than 2 million tons of glycerol is being produced as a biodiesel production by-product [61].

Crude glycerol, which is being created during the biodiesel production process, contains such impurities as alcohols, heavy metals, water and various salts, which is the reason why it is necessary to treat industrial glycerol prior to its utilization in other sectors [2], [61]. Due to the impurities, transportation costs and low market prices, market for untreated glycerol is limited. As a result, biodiesel producers often sell glycerol as a fuel, which is a solution associated with low profit margins. New and innovative technological solutions and an introduction of more effective glycerol utilization solutions could help in further development of the whole biodiesel industry. In SCO production both treated and untreated glycerol can be used [62], resulting in overall reduction of production costs, since the untreated glycerol has a very low market price (2-5 EUR per kilogram) [63] and a relatively small amount of glycerol must be added into the medium (20-100 g/L). Glycerol utilization in SCO production offers an opportunity to produce a product with high added value and enables more profitable 
utilization of glycerol. Utilization of glycerol in SCO production is widely described in numerous publications [28]-[38] with extremely high SCO yield reported when using Schizochytrium sp. (Table 1).

\subsubsection{Sodium Gluconate}

Sodium gluconate is a sodium salt of gluconic acid, which is very soluble in water and is therefore found in industrial wastewaters where it is produced and used. Sodium gluconate is widely used in the textile industry, dyeing, printing, metal surface treatment as well as a cleaning agent and as a chelating agent. Gouda et al. reported that sodium gluconate can be used as a carbon source for oleaginous bacteria Gordonia sp. and Rhodococcus opacus cultivation [39].

\subsubsection{Butanol Wastewaters}

In order to replace the production of butanol from petroleum, it can be produced using an acetone-butanol-ethanol fermentation process in which anaerobic bacteria ferment carbohydrates and synthesize acetone, butanol and ethanol. This process is environmentally friendly, uses renewable resources such as starch or glucose and eliminates the need for fossil resources. After fermentation, more than $99 \%$ of the produced acetone, butanol and ethanol are recovered from the fermented culture medium, but the used medium (butanol wastewater) is characterized by high chemical oxygen demand (COD) values $(23560 \mathrm{ppm})$ due to residual carbohydrates and organic acids such as acetic and butyric acid [40]. In order to treat butanol wastewater and reduce the negative environmental impact that these residues would have if they entered the environment previously untreated, they can be used as a medium base for cultivating oleaginous microorganisms. Without addition of additional nutrients Peng et al. [40] cultivated Trihosporon dermatis in butanol wastewater and reported relatively low SCO yield, while significantly reducing COD levels in the wastewater. In the future, combination of butanol wastewater with other carbon-rich waste products could ensure significant increase in SCO yields.

\subsection{Sources for Photosynthetic Microorganisms}

\subsection{1. $\mathrm{CO}_{2}$ as Carbon Source}

Today it is well known as $\mathrm{CO}_{2}$ becomes more potent in atmosphere, overall temperatures keep rising. Due to $\mathrm{CO}_{2}$ effects on climate change, there are more and more attempts to remove $\mathrm{CO}_{2}$ from the atmosphere. Hence carbon capture and storage (CCS) technologies have been developed in recent years [64], technologies like $\mathrm{CO}_{2}$ capture by ionic solvents and its storage deep in the ground, so that it cannot re-escape into the atmosphere [65]. On the downside, these technologies require a lot of energy. Alternatively, autotrophic organisms, such as plants and microorganisms can be used to assimilate $\mathrm{CO}_{2}$ into biomass by photosynthesis [66]. As mentioned above, microorganisms are more effective for $\mathrm{CO}_{2}$ capture. In line with this review, we analysed the potential of $\mathrm{CO}_{2}$ usage as a carbon source for SCO production. Industries such as steel and oil refining, coal and natural gas, as well as fertiliser production are the main producers of $\mathrm{CO}_{2}$ [65], [67].

There have been attempts to develop an economically feasible system for $\mathrm{CO}_{2}$ assimilation by using algae simultaneously for effluent wastewater treatment from steel production plants. [68] Due to the low $\mathrm{C} / \mathrm{N}$ ratio of wastewater [69], autotrophic microorganism cultivation would be suitable in such case. As mentioned above, one of the main carbon dioxide producing industries is the fertiliser production industry [70]. According to the Centre for 
European Policy Studies report from 2014, more than 130 million tonnes of ammonium were produced globally in 2012, with the main producers being China with 44 million tonnes, India 12 million tonnes and Russia with 10 million tonnes [71]. The Intergovernmental Panel on Climate Change (IPCC) in 2006 published Guidelines for National Greenhouse Gas Inventories, in these guidelines IPCC states that 2.104 tonnes of $\mathrm{CO}_{2}$ are produced from every ton of ammonium produced [72]. Although IPCC calculations are derived from European average values for specific energy consumption (mix of modern and older plants), assuming this emission factor is applicable on the global scale, we can calculate that 274 million tonnes of $\mathrm{CO}_{2}$ are produced every year from ammonia production alone. This is an untapped resource for SCO production autotrophically.

In addition to light, source of nitrogen and carbon dioxide, algae need phosphorus and potassium. Recommendations of N/P/K proportions vary from equal amounts of nitrogen, phosphorous and potassium for $C$. vulgaris cultivation [73] to a N/P/K ratio of 6/1/1 for Dunaliella tertiolecta cultivation [74]. Standard mediums, like Soil extract [75] and Bold's Basal Medium [76] for laboratory cultivation give ratios of $1 / 1 / 2$, leaving phosphorus as limiting. The amount of potential biomass yield from certain amounts of $\mathrm{CO}_{2}$ are described by two stoichiometric equations, depending on nitrogen source used [77], [78]:

$$
\begin{aligned}
& 0.81 \mathrm{CO}_{2}+0.73 \mathrm{H}_{2} \mathrm{O}+0.12 \mathrm{NH}_{3}+\text { minerals } \stackrel{h v}{\rightarrow} 0.81 \mathrm{C} \text {-mole }+\mathrm{O}_{2}, \\
& 0.71 \mathrm{CO}_{2}+0.59 \mathrm{H}_{2} \mathrm{O}+0.101 \mathrm{NO}_{3}{ }^{-}+\text {minerals } \stackrel{h v}{\rightarrow} 0.71 \mathrm{C} \text {-mole }+\mathrm{O}_{2} .
\end{aligned}
$$

These equations can give a rough estimate of the required amount of nitrogen, other essential elements are excluded from these equations due to negligible amounts of these elements as seen in the elemental composition of green algae $C$. vulgaris $\mathrm{C}_{60} \mathrm{H}_{9} \mathrm{O}_{21} \mathrm{~N}_{6.5}$ $\mathrm{P}_{0.8} \mathrm{~S}_{0.08}$ [79], as according C-mole of $C$. vulgaris is $\mathrm{CH}_{0.15} \mathrm{O}_{0.35} \mathrm{~N}_{1.08} \mathrm{P}_{0.01} \mathrm{~S}_{0}$. This leads to nitrogen and phosphorus being the main nutrients causing algae blooms and eutrophication by wastewaters flushing into natural bodies of water. So it makes perfect sense that microscopic algae have already been used for tertiary wastewater treatment [80]. In this case, inorganic nitrogen and phosphates are used as valuable nutrients for algal growth. Tertiary treatment of wastewater is often skipped due to high expenses [81], though if oleaginous algae as $C$. vulgaris is chosen for this treatment, financial gains could be potentially made after biomass collection and oil extraction. As $C$. vulgaris in autotrophic growth conditions can yield $38 \%$ lipids of its dry cell weight [82]. In addition, similar to algal single cell protein production, costs of SCO production from algae can be lower due to the fact that at least part of the required nutrients are provided by waste [83] - wastewater and $\mathrm{CO}_{2}$ emissions.

According to a 2016 study looking into Barcelona's (Spain) wastewater treatment plant (WWTP), after secondary treatment a considerable amount of potassium, phosphates, nitrates, and ammonium are present in the effluent $-36,14,51$ and $30 \mathrm{mgL}^{-1}$ accordingly [84]. This gives a rough $\mathrm{N} / \mathrm{P} / \mathrm{K}$ ratio of $9 / 1 / 9$. As mentioned above, $\mathrm{N} / \mathrm{P} / \mathrm{K}$ ratios vary considerably, in Collet et al. study $C$. vulgaris was cultivated [85] in open raceways with N/P/K ratios being closer to $8 / 2 / 1$, N/P ratio in this case is close to abovementioned effluent from secondary wastewater treatment plant in Barcelona [84]. This would leave excess potassium in the effluent from tertiary treatment. This would leave SCO producers with choice - to supplement secondary wastewater effluent with additional nitrogen and phosphorus source or let the extra potassium go to waste and avoid extra costs. According to Yakushev et al. research, $229 \mathrm{hm}^{3}$ of wastewater is treated in the same Barcelona WWTP in a single year, roughly $0.627 \mathrm{hm}^{3} \cdot \mathrm{day}^{-1}$ [86]. By using two abovementioned Eq. (1) and Eq. (2) for biomass 
production from $\mathrm{NH}_{3}$ and $\mathrm{NO}_{3}{ }^{-}$accordingly, required $\mathrm{CO}_{2}$ can be calculated. As a result, $504.8 \mathrm{~g} \mathrm{~L}^{-1}$ of $\mathrm{CO}_{2}$ is needed for complete removal of $\mathrm{NO}_{3}{ }^{-}$from medium, and an additional $494.2 \mathrm{~g} \mathrm{~L}^{-1}$ of $\mathrm{CO}_{2}$ for complete $\mathrm{NH}_{3}$ removal. Assuming there is no deficit of other nutrients, 229 kilo tonnes of $\mathrm{CO}_{2}$ could be assimilated in a course of a year from the abovementioned WWTP, in these conditions $445 \mathrm{~g}$ of $C$. vulgaris biomass could be produced from every $1 \mathrm{~kg}$ of carbon dioxide.

\section{Conclusions}

In the scope of this review only a few industrial by-products were considered for SCO production. As shown in this review, every waste or by-product could be used for higher value-added product production, as well as for reduction of an industry's burden on the environment as in case with wastewaters, carbon dioxide and butanol wastewaters.

When considering waste and by-product usage for SCO production, a couple of things should be taken into account:

- Oil quality and purity requirements;

- Desired fatty acid profile and the respective microorganisms and their requirements for growth and oil production conditions;

- Additional expenses for substrate pre-treatment and transportation;

- Concentration of potential inhibitors.

There is no defined answer to what would be the best substrate for SCO production, as all abovementioned criteria should be considered. For example, carbon dioxide would require the least pre-treatment, but for economic reasons it should be coupled with effluents from secondary wastewater treatment, and only photosynthetic microorganisms could be cultivated this way - this leads to demand of vast land areas, as with today's technologies net energy ratio is greater than one only in open pond cultivation systems [87]. When considering PMS hydrolysate, not only additional costs of pre-fermentations should be taken into account, but also inhibitor presence [88] and effects on chosen microorganisms. As mentioned in previous studies [1], [7], [13], [17] each waste material must be evaluated not only in regard to its economic feasibility, but should be compared to already existing or potentially emerging competing sectors.

\section{ACKNOWLEDGEMENT}

The work has been supported by ERAF project KC-PI-2017/60 "Supercritical Omega-3 oil from production by-products" managed by the Investment and Development Agency of Latvia (LIAA).

\section{REFERENCES}

[1] Spalvins K., Ivanovs K., Blumberga D. Single cell protein production from waste biomass: review of various agricultural by-products. Agronomy Research 2018:16(S2):1493-1508. doi:10.15159/ar.18.129

[2] Johnson D. T., Taconi K. A. The glycerin glut: options for value-added conversion of crude glycerol resulting from biodiesel production. Environmental Progress 2007:26(4):338-348. doi:10.1002/ep.10225

[3] Kost C., et al. Levelized cost of electricity renewable energy technologies. Study. Fraunhofer ISE, 2013.

[4] Browne J., Nizami A. S., Thamsiriroj T., Murphy J. D. Assessing the cost of biofuel production with increasing penetration of the transport fuel market: A case study of gaseous biomethane in Ireland. Renewable and Sustainable Energy Reviews 2011:15(9):4537-4547. doi:10.1016/j.rser.2011.07.098

[5] Werpy T., Petersen G. Top Value Added Chemicals from Biomass. Volume I - Results of Screening for Potential Candidates from Sugars and Synthesis Gas. United States Department of Energy, 2004. 
[6] FitzPatric. M., Champagne P., Cunningham M. F., Whitney R. A. A biorefinery processing perspective: Treatment of lignocellulosic materials for the production of value-added products. Bioresource Technology 2010:101(23):89158922. doi:10.1016/j.biortech.2010.06.125

[7] Spalvins K., Zihare L., Blumberga D. Single cell protein production from waste biomass: comparison of various industrial by-products. Energy Procedia 2018:147:409-418. doi:10.1016/j.egypro.2018.07.111

[8] El-Bakry M., et al. From Wastes to High Value Added Products: Novel Aspects of SSF in the Production of Enzymes. Journal Critical Reviews in Environmental Science and Technology 2015:45(18). doi:10.1080/10643389.2015.1010423

[9] Pinzi S., Garcia I. L., J. Lopez-Gimenez F. J., DeCastro M. D. L., Dorado G., Dorado M. P. The ideal vegetable oil-based biodiesel composition: a review of social, economical and technical implications. Energy and Fuels 2009:23(5):2325-2341. doi:10.1021/ef801098a

[10] Ratledge C. Microbial oils: an introductory overview of current status and future prospects. OCL 2013:20(6):D602. doi:10.1051/oc1/2013029

[11] Finco A. M. O., Mamani L. D. G., Carvalho J. C., Pereira G. V. M., Soccol V. T., Soccol C. R. Technological trends and market perspectives for production of microbial oils rich in omega-3. Critical Reviews in Biotechnology 2016:37(5):1-16. doi:10.1080/07388551.2016.1213221

[12] Huang C., Chen X., Xiong L., Chen X., Ma L., Chen Y. Single cell oil production from low-cost substrates: the possibility and potential of its industrialization. Biotechnology Advances 2013:31(2):129-139. doi:10.1016/i.biotechadv.2012.08.010

[13] Spalvins K., Blumberga D. Single cell oil production from waste biomass: review of applicable agricultural by-products. Agronomy Research 2019:17(3):833-849. doi:10.15159/ar.19.039

[14] Zuta C. P., Simpson B. K., Chan H. M., Phillips L. Concentrating PUFA from mackerel processing waste. Journal of the American Oil Chemists Society 2003:80(9):933-936. doi:10.1007/s11746-003-0799-5

[15] Boyle N. R, Morgan J. A. Computation of metabolic fluxes and efficiencies for biological carbon dioxide fixation. Metabolic Engineering 2011:13(2):150-158. doi:10.1016/j.ymben.2011.01.005

[16] Mekonnen M. M, Hoekstra A. Y. Water footprint benchmarks for crop production: A first global assessment. Ecological Indicators 2014:46:214-223. doi:10.1016/j.ecolind.2014.06.013

[17] Spalvins K., Blumberga D. Production of fish feed and fish oil from waste biomass using microorganisms: overview of methods analyzing resource availability. Environmental and Climate Technologies 2018:22(1):149-154. doi:10.2478/rtuect-2018-0010

[18] Li Q., Du W., Liu D. Perspectives of microbial oils for biodiesel production. Appl. Microbiol. Biotechnol. 2008:80(5):749-756. doi:10.1007/s00253-008-1625-9

[19] Leiva-Candia D. E., Pinzi S., Redel-macías M. D., Koutinas A., Webb C., Dorado M. P. The potential for agro-industrial waste utilization using oleaginous yeast for the production of biodiesel. Fuel 2014:123:33-42. doi:10.1016/j.fuel.2014.01.054

[20] Jin M., Slininger P. J., Dien B. S., Waghmode S., Moser B. R., Orjuela A., Sousa L. C., Balan V. Microbial lipid-based lignocellulosic biorefinery: feasibility and challenges. Trends in Biotechnology 2015:33(1):43-54 doi:10.1016/j.tibtech.2014.11.005

[21] Patel A., Arora N., Sartaj K., Pruthi V., Pruthi P. A. Sustainable biodiesel production from oleaginous yeasts utilizing hydrolysates of various non-edible lignocellulosic biomasses. Renewable and Sustainable Energy Reviews 2016:62:836-855. doi:10.1016/j.rser.2016.05.014

[22] Qin L., Liu L., Zeng A., Wei D. Bioresource Technology From low-cost substrates to Single Cell Oils synthesized by oleaginous yeasts. Bioresource Technology 2017:245:1507-1519. doi:10.1016/j.biortech.2017.05.163

[23] Chanda S., Chakrabarti S. Plant origin liquid waste: A resource for single cell protein production by yeast. Bioresource Technology 1996:57(1):51-4. doi:10.1016/0960-8524(96)00053-3

[24] Deeba F., Pruthi V., Negi Y. S. Converting paper mill sludge into neutral lipids by oleaginous yeast Cryptococcus vishniaccii for biodiesel production. Bioresource Technology 2015:213:96-102. doi:10.1016/j.biortech.2016.02.105

[25] Zhou W., Gong Z., Zhang L., Liu Y., Yan J., Zhao M. Feasibility of lipid production from waste paper by the oleaginous yeast Cryptococcus curvatus. BioResources 2017:12(3):5249-5263. doi:10.15376/biores.12.3.5249-5263

[26] Annamalai N., Sivakumar N., Oleskowicz-Popiel P. Enhanced production of microbial lipids from waste office paper by the oleaginous yeast Cryptococcus curvatus. Fuel 2018:217:420-426. doi:10.1016/j.fuel.2017.12.108

[27] Angerbauer C., Siebenhofer M., Mittelbach M., Guebitz G. M. Conversion of sewage sludge into lipids by Lipomyces starkeyi for biodiesel production. Bioresource Technology 2008:99(8):3051-3056. doi:10.1016/j.biortech.2007.06.045

[28] Li J., Liu R., Chang G., Li X., Chang M., Liu Y., Jin Q., Wang X. A strategy for the highly efficient production of docosahexaenoic acid by Aurantiochytrium limacinum SR21 using glucose and glycerol as the mixed carbon sources. Bioresource Technology 2015:177C:51-57. doi:10.1016/j.biortech.2014.11.046

[29] Patil K. P, Gogate P. R. Improved synthesis of docosahexaenoic acid (DHA) using Schizochytrium limacinum SR21 and sustainable media. The Chemical Engineering Journal 2015:268:187-196. doi:10.1016/j.cej.2015.01.050

[30] Ethier S., Woisard K., Vaughan D., Wen Z. Continuous culture of the microalgae Schizochytrium limacinum on biodiesel-derived crude glycerol for producing docosahexaenoic acid. Bioresource Technology 2010:102(1):88-93 doi:10.1016/j.biortech.2010.05.021 
[31] Meesters P. A. E. P., Huijberts G. N. M., Eggink G. High-cell-density cultivation of the lipid accumulating yeast Cryptococcus curvatus using glycerol as a carbon source. Applied Microbiology Biotechnology 1996:45(5):575-579. doi:10.1007/s002530050731

[32] Chang G., Gao N., Tian G., Wu Q., Chang M., Wang X. Improvement of docosahexaenoic acid production on glycerol by Schizochytrium sp. S31 with constantly high oxygen transfer coefficient. Bioresource Technology 2013:142:400 406. doi:10.1016/j.biortech.2013.04.107

[33] Munch G., Sestric R., Sparling R., Levin D. B., Cicek N. Lipid production in the under-characterized oleaginous yeasts, Rhodosporidium babjevae and Rhodosporidium diobovatum, from biodiesel-derived waste glycerol. Bioresource Technology 2015:185:49-55. doi:10.1016/j.biortech.2015.02.051

[34] Kitcha S., Cheirsilp B. Screening of oleaginous yeasts and optimization for lipid production using crude glycerol as a carbon source. Energy Procedia 2011:9:274-282. doi:10.1016/j.egypro.2011.09.029

[35] Sestric R., Munch G., Cicek N., Sparling R., Levin D. B. Growth and neutral lipid synthesis by Yarrowia lipolytica on various carbon substrates under nutrient-sufficient and nutrient-limited conditions. Bioresource Technology 2014:164:41-46. doi:10.1016/j.biortech.2014.04.016

[36] Papanikolaou S., Aggelis G. Biotechnological valorization of biodiesel derived glycerol waste through production of single cell oil and citric acid by Yarrowia lipolytica. Lipid Technology 2009:21(4):83-87. doi:10.1002/lite.200900017

[37] Poli J. S., da Silva M. A. N., Siqueira E. P., Pasa V. M. D., Rosa C. A., Valente P. Microbial lipid produced by Yarrowia lipolytica QU21 using industrial waste: a potential feedstock for biodiesel production. Bioresource Technology 2014:161:320-326. doi:10.1016/j.biortech.2014.03.083

[38] Papanikolaou S., Aggelis G. Lipid production by Yarrowia lipolytica growing on industrial glycerol in a single. Bioresource Technology 2002:82:43-49. doi:10.1016/S0960-8524(01)00149-3

[39] Gouda M. K., Omar S. H., Aouad L. M. Single cell oil production by Gordonia sp. DG using agro-industrial wastes. World Journal of Microbiology and Biotechnology 2008:24(9):1703-1711. doi:10.1007/s11274-008-9664-Z

[40] Peng W. F., Huang C., Chen X. F., Xiong L., Chen X., Chen Y., Ma L. Microbial conversion of wastewater from butanol fermentation to microbial oil by oleaginous yeast Trichosporon dermatis. Renewable Energy 2013:55:31-34. doi:10.1016/j.renene.2012.12.017

[41] Huang X., Shen Y., Luo H., Liu J., Liu J. Enhancement of extracellular lipid production by oleaginous yeast through preculture and sequencing batch culture strategy with acetic acid. Bioresource Technology 2018:247:395-401. doi:10.1016/j.biortech.2017.09.096

[42] Minowa T., Yokoyama S., Kishimoto M. Oil production from algal cells of Dunaliella tertiolecta by direct thermochemical liquefaction. Fuel 1995:74(12):1735-1738. doi:10.1016/0016-2361(95)80001-X

[43] Liang Y., Sarkany N., Cui Y. Biomass and lipid productivities of Chlorella vulgaris under autotrophic, heterotrophic and mixotrophic growth conditions. Biotechnol. Lett. 2009:31(7):1043-1049. doi:10.1007/s10529-009-9975-7

[44] Ochoa de Alda J. A. G. Feasibility of recycling pulp and paper mill sludge in the paper and board industries. Resources, Conservation and Recycling 2008:52(7):965-972. doi:10.1016/j.resconrec.2008.02.005

[45] Bajpai P. Recycling and Deinking of Recovered Paper. London and New York: Elsevier, 2014.

[46] Kuokkanen T., Nurmesniemi H., Pöykiö R., Kujala K., Kaakinen J., Kuokkanen M. Chemical and leaching properties of paper mill sludge. Chemical Speciation and Bioavailability 2008:20(2):111-122. doi:10.3184/095422908X324480

[47] Scott G. M., Abubakr S., Smith A. Sludge characteristics and disposal alternatives for the pulp and paper industry. Proceedings International Environmental Conference, Atlanta, GA, TAPPI PRESS, 1995.

[48] Trevelyan W. E., Forrest R. S., Harrison J. S. Determination of yeast carbohydrates with the anthrone reagent. Nature 1952:170:626-627. doi:10.1038/170626a0

[49] Ivarson K. C., Morita H. Single-cell protein by acid-tolerant fungus Scytalidium acidophilum from acid hydrolysates of waste paper. Applied and Environmental Microbiology 1982:43(3):643-647.

[50] Vishniac H. S., Hempfling W. P. Cryptooccus vishniacii sp. nov., an Antarctic Yeast. International Journal of Systematic Bacteriology 1979:29(2):153-158. doi:10.1099/00207713-29-2-153

[51] Fytili D., Zabaniotou A. Utilization of sewage sludge in EU application of old and new methods - A review. Renewable and Sustainable Energy Reviews 2008:12(1):116-140. doi:10.1016/j.rser.2006.05.014

[52] Commission of European Communities. Council Directive 91/271/EEC of 21 March 1991 concerning urban waste-water treatment (amended by the 98/15/EC of 27 February 1998).

[53] Davis R. D. The impact of EU and UK environmental pressures on the future of sludge treatment and disposal. Water and Environmental Journal 1996:10(1):65-69. doi:10.1111/j.1747-6593.1996.tb00010.x

[54] Eurostat. EU population up to nearly 513 million on 1 January 2018, 2018.

[55] Kargbo D. M. Biodiesel production from municipal sewage sludges. Energy and Fuels 2010:24(5):2791-2794. doi:10.1021/ef1001106

[56] Sommers L. E., Nelson D. W., Yost K. J. Variable Nature of Chemical Composition of Sewage Sludges. Journal of Environmental Quality 2010:5(3):303-306. doi:10.2134/jeq1976.00472425000500030017x

[57] Sommers L. E. Chemical Composition of Sewage Sludges and Analysis of Their Potential Use as Fertilizers. Journal of Environmental Quality 2010:6(2):225-232. doi:10.2134/jeq1977.00472425000600020026x

[58] European Biodiesel Board. Statistics. the EU biodiesel industry [Online]. [Accessed 17.07.2018] Available: http://www.ebb-eu.org/stats.php\# 
[59] Renewables. Global status report. REN21. 2015 [Online]. [Accessed 09.05.2018]. Available at: http://www.ren21.net/wp-content/uploads/ 2015/07/REN12-GSR2015_Onlinebook_low1.pdf

[60] United States Department of Energy (USDE). Biodiesel - Just the Basics. Final. [Online]. [Accessed 17.07.2018]. Available: https://www1.eere.energy.gov/vehiclesandfuels/pdfs/basics/jtb_biodiesel.pdf

[61] Ciriminna R., Della Pina C., Rossi M., Pagliaro M. Understanding the glycerol market. European Journal of Lipid Science and Technology 2014:116(10):1432-1439. doi:10.1002/ejlt.201400229

[62] Dobrowolski A., Mituła P., Rymowicz W., Mirończuk A. M. Efficient conversion of crude glycerol from various industrial wastes into single cell oil by yeast Yarrowia lipolytica. Bioresource Technology 2016:207:237-243. doi:10.1016/j.biortech.2016.02.039

[63] Kong P. S., Aroua M. K., Ashri Wan Daud W. M. Conversion of crude and pure glycerol into derivatives: A feasibility evaluation. Renewable and Sustainable Energy Reviews 2016:63:533-555. doi:10.1016/j.rser.2016.05.054

[64] Werz P. D. L., Kainz J., Rieger B. Thermo- and pH-Responsive Nanogel Particles Bearing Secondary Amine Functionalities for Reversible Carbon Dioxide Capture and Release. Macromolecules 2015:48(18):6433-6439. doi:10.1021/acs.macromol.5b01367

[65] Boot-Handford M. E., et al. Carbon capture and storage update. Energy and Environtal Science 2014:7(130):130-189. https://doi.org/10.1039/C3EE42350F

[66] Simkin A. J., McAusland L., Headland L. R., Lawson T., Raines C. A. Multigene manipulation of photosynthetic carbon assimilation increases $\mathrm{CO} 2$ fixation and biomass yield in tobacco. Journal of Experimental Botany 2015:66(13):4075-4090. doi:10.1093/jxb/erv204

[67] Spalvins K., Ivanovs K., Blumberga D. Single cell protein production from waste biomass : comparison of various agricultural by-products. Agronomy research 2017:16(2):1493-1508. doi:10.15159/ar.18.129

[68] Yun Y., Yang J., Lee S. B., Park J. M., Lee C. Carbon Dioxide Fixation by Algal Cultivation Using Wastewater Nutrients. Journal of Chemical technology and Biotechnology 2002:69(4):451-455. doi:10.1002/(SICI)1097-4660(199708)69:43.3.CO;2-D

[69] Park J. B. K., Craggs R. J. Wastewater treatment and algal production in high rate algal ponds with carbon dioxide addition. Water Science and Technology 2010:5:633-640. doi:10.2166/wst.2010.951

[70] Worrell E., Bernstein L., Roy J., Price L., Harnisch J. Industrial energy efficiency and climate change mitigation. Energy Efficience 2009:2(2):109-123. doi:10.1007/s12053-008-9032-8

[71] Egenhofer C., et al. Final report for a study on composition and drivers of energy prices and costs in energy intensive industries: the case of the chemical industry - ammonia. Sensemaking Symp. 2014:1-33.

[72] Guidelines for National Greenhouse Gas Inventories: Industrial Processes and Product Use 2006. IPCC, $2006: 3$.

[73] Saad H. Ammar. Cultivation of Microalgae Chlorella vulgaris in airlift photobioreactor for Biomass Production using commercial NPK nutrients. Al-Khwarizmi Eng. J. 2016:12(1):90-99.

[74] Roleda M. Y., Slocombe S. P., Leakey R. J. G., Day J. G., Bell E. M., Stanley M. S. Effects of temperature and nutrient regimes on biomass and lipid production by six oleaginous microalgae in batch culture employing a two-phase cultivation strategy. Bioresource Technology 2013:129:439-449. doi:10.1016/j.biortech.2012.11.043

[75] Li Y., Horsman M., Wang B., Wu N., Lan C. Q. Effects of nitrogen sources on cell growth and lipid accumulation of green alga Neochloris oleoabundans. Applied Microbiology and Biotechnology 2008:81(4):629-636. doi:10.1007/s00253-008-1681-1

[76] Blair M. F., Kokabian B., Gude V. G. Light and growth medium effect on Chlorella vulgaris biomass production. Journal of Environtal Chemical Engineering 2014:2(1):665-674. doi:10.1016/j.jece.2013.11.005

[77] Pirt S. J., Lee Y.-K., Richmond A., Pirt M. W. The photosynthetic efficiency of Chlorella biomass growth with reference to solar energy utilisation Journal of Chemical Technology and Biotechnology 1980:30(1):25-34 doi:10.1002/jctb.503300105

[78] Javanmardian M. Continuous Photoautotrophic Cultures of the Eukaryotic Alga. System 1992:39:487-497. doi:10.1002/bit.260390503

[79] Vijayakumar J., Anderson G. A., Gent S. P., Rajendran A. Calculation of biomass capacity of Algae based on their elemental composition, 2013.

[80] Hammouda O., Gaber A., Abdel-Raouf N. Microalgae and waste-water treatment. Ecotoxicology and Environmental Safety 1994:31(3):205-210. doi:10.1006/eesa.1995.1064

[81] de la Noüe J., Laliberté G., Proulx D. Algae and waste water. Journal of Applied Phycology 1992:4(3):247-254. doi:10.1007/BF02161210

[82] Liang Y., Sarkany N., Cui Y. Biomass and lipid productivities of Chlorella vulgaris under autotrophic, heterotrophic and mixotrophic growth conditions. Biotechnology Letters 2009:31(7):1043-1049. doi:10.1007/s10529-009-9975-7

[83] Moraine R., Shelef G., Meydan A., Levi A. Algal single cell protein from wastewater treatment and renovation process. Biotechnology and Bioengineering 1979:21(7):1191-1207. doi:10.1002/bit.260210709

[84] Guaya D., Hermassi M., Valderrama C., Farran A., Cortina J. L. Recovery of ammonium and phosphate from treated urban wastewater by using potassium clinoptilolite impregnated hydrated metal oxides as N-P-K fertilizer. Journal of Environmental Chemical Engineering 2016:4(3):3519-3526. doi:10.1016/j.jece.2016.07.031

[85] Collet P., Hélias Arnaud A., Lardon L., Ras M., Goy R. A., Steyer J. P. Life-cycle assessment of microalgae culture coupled to biogas production. Bioresource Technology 2011:102(1):207-214. doi:10.1016/j.biortech.2010.06.154 
[86] Yakushev A., Newton E.V. Redox Interfaces In Marine Waters. Chemical Structure of Pelagic Redox Interfaces. Handbook of Environmetnal Chemistry 2013:22:1-12. doi:10.1007/698_2012_167

[87] Jorquera O., Kiperstok A., Sales E. A., Embiruçu M., Ghirardi M. L. Comparative energy life-cycle analyses of microalgal biomass production in open ponds and photobioreactors. Bioresource Technology 2010:101(4):1406-1413. doi:10.1016/j.biortech.2009.09.038

[88] Rajeshwari K. V., Balakrishnan M., Kansal A., Lata K., Kishore V. V. N. State-of-the-art of anaerobic digestion technology for industrial wastewater treatment. Renewable and Sustainable Energy Reviews 2000:4(2):135-156. doi:10.1016/S1364-0321(99)00014-3 